\title{
Sequences up- and down-stream of the DIS hairpin are important for HIV-1 replication
}

\author{
Nikki van Bel', Atze T Das, Ben Berkhout \\ From Frontiers of Retrovirology 2011 \\ Amsterdam, The Netherlands. 3-5 October 2011
}

\section{Background}

Infectious HIV-1 virions contain two copies of the viral RNA genome, which are non-covalently linked through sequence elements in the 5 'untranslated leader region (5'UTR). This leader region is highly structured and can expose the Dimerization Initiation Signal (DIS) in a stem-loop structure. Because of the palindromic nature of the hairpin loop, a kissing-loop dimer (KLD) interaction between two DIS elements can initiate dimer formation in vitro and subsequent RNA rearrangements can result in a more stable extended dimer (ED). Unpublished findings from our laboratory suggested that the unpaired nucleotides that flank the DIS stemloop element may have a role in HIV-1 dimer formation. We therefore probed the function of these sequences during HIV-1 replication.

\section{Materials and methods}

The sequences immediately up- and down-stream of the DIS hairpin were either mutated or randomized in the context of the HIV-1 molecular clone pLAI. The virus libraries with randomized sequences were cultured for several months to select for replication-competent variants. The effect of the mutations on viral gene expression, dimer formation, packaging and replication was analyzed.

\section{Results}

We first determined the sequence constraints for the nucleotides flanking the DIS hairpin to support optimal virus replication. For this, we randomized these sequences and started multiple long-term cultures to select for replication-competent variants. This analysis

\footnotetext{
Laboratory of Experimental Virology, Department of Medical Microbiology, Center for Infection and Immunity Amsterdam (CINIMA), Academic Medical Center of the University of Amsterdam, The Netherlands
}

revealed a strong preference for the wild-type sequence, but with some minor variations. Overall, these segments seem to play an important role in virus replication in a sequence-specific manner. Mutation of these sequences did not affect HIV-1 gene expression, but reduced viral replication. Further analyses of the precise replication step affected are ongoing.

\section{Conclusions}

The single-stranded nucleotides flanking the HIV-1 DIS hairpin are important for efficient HIV-1 replication. Their role in viral RNA dimerization will be studied in further detail.

Published: 3 October 2011

doi:10.1186/1742-4690-8-S2-P68

Cite this article as: van Bel et al:: Sequences up- and down-stream of the DIS hairpin are important for HIV-1 replication. Retrovirology 20118 (Suppl 2):P68.

Submit your next manuscript to BioMed Central and take full advantage of:

- Convenient online submission

- Thorough peer review

- No space constraints or color figure charges

- Immediate publication on acceptance

- Inclusion in PubMed, CAS, Scopus and Google Scholar

- Research which is freely available for redistribution 